\title{
ソーマサイト生成硫酸塩劣化 一劣化機構の整理とリスクの評価方法のレビュー
}

\author{
吉田 夏樹*1・山田 一夫*2
}

\begin{abstract}
概 要 欧米諸国において，コンクリートの新たな化学的劣化現象「ソーマサイト生成硫酸塩劣化 (Thaumasite form of Sulfate Attack)」が注目されている。ソーマサイトとは，低温環境抢よび水の存在下に抢いて，主に土壌中から硫酸 イオン, 炭酸塩骨材から炭酸イオンが供給されると, これらの物質とケイ酸カルシウム水和物が反応して生成する物質で, セメント組織を軟化させ，コンクリート表面のひび割れや崩壊を導く。筆者らは，欧米諸国による報告などから，この劣 化現象に関する様々な知見を得たので，本稿において整理し，情報提供を行った。

キーワード：ソーマサイト, 硫酸塩劣化, 硫酸イオン, 炭酸イオン, 炭酸塩骨材, 低温環境, 黄鉄鉱の酸化
\end{abstract}

1.はじめに

コンクリートの耐久性に関する問題の一つに，化学物 質がコンクリートに作用し，コンクリートの劣化を導く 「化学的侵食」がある。化学的侵食の主な現象には，酸 （硫酸，酸性雨，脂肪酸など）によるセメント水和物の 分解，硫酸塩（ $\mathrm{Na}_{2} \mathrm{SO}_{4}, \mathrm{CaSO}_{4}, \mathrm{MgSO}_{4}$ など）の作用 による膨張性化合物（エトリンガイト，二水セッコウな ぞ）の生成などがあり，国内においてもいくつかの事例 が報告されている1。

この化学的侵食に関して, 近年, 欧米諸国において新 たな劣化現象が注目されている。その現象とは，「ソー マサイト生成硫酸塩劣化 (TSA：Thaumasite form of Sulfate Attack)」之呼ばれるもので, 硫酸塩の化学的 作用に，ある限定的な条件（後に詳しく述べる）が加わ ると，「ソーマサイト (thaumasite)」之呼ばれる鉱物 が生成し、コンクリートが顕著に劣化する現象であ る2),3)。

TSA は、これまで硫酸塩劣化環境下に扔いて特に問 題とされてきた，「エトリンガイト生成」「水セッコ ウ生成」扔よび「ミラビライト $\left(\mathrm{Na}_{2} \mathrm{SO}_{4} \cdot 10 \mathrm{H}_{2} \mathrm{O}\right)$ 生成 とは全く異なる現象を示すあのである ${ }^{10,4)}$

日本に扔いては，未だ劣化事例は報告されていないか， 一部の特定地域には硫酸塩を含む土壤が存在することな どから，TSAのメカニズムを把握しておく必要がある ものと考えられる。

筆者らは，この新たな劣化現象に関して，欧米諸国に 上る報告などから, 分析方法, 生成メカニズム, 劣化入 カニズム，および対策例などに関する知見を得たので， 広く情報提供することを目的として，本稿において簡単

＊1よしだ・なつき/(盺日本建築総合試験所材料部 材料試験室

*2ややまだ・かずお/太平洋セメント(侏)中央研究所セメント化学チー ムリーダー（正会員）
に整理したい。

2. ソーマサイト生成が注目されるに至った経緯

この劣化が注目される発端となったのは, 1998 年, イギリス南西部で生じた劣化事例で, Gloucester とい う街を走る M5 motorway（高速道路）の鉄筋コンクリー 卜橋脚に扔いて, 硫酸塩を含んだ土壌に接する地中部分 に, ソーマサイト生成による大規模な劣化が見つかっ た5)。写真-1 が劣化の状況を示したものであるが，コン クリート表層の大部分が白色の物質に変化し, ひどく劣 化している様子が誢える。この白色物質が「ソーマサイ ト」である。

ソーマサイト生成によるセメント系材料の劣化は, 1960 年代半ばに北アメリカで見つかり》，その後もヨー ロッパ各国を中心に事例がいくつか報告されていたが,

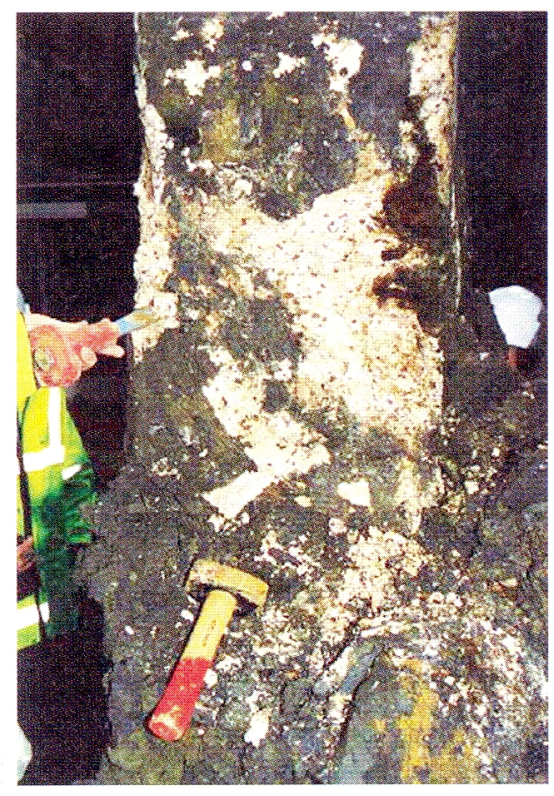

copyright $\mathrm{BRE}$

写真-1 M5 motorwayにおける橋脚の劣化状況 ${ }^{6) * 1}$ 
上述した高速道路という重要な社会基盤構造物において 確認され，ようやく危機感を抱いて広く認識されること となった。

2002 年 6 月には, M5 motorway の調査において中 心的な役割を担った機関である BRE (Building Research Establishment）が主催して，第一回の国際 会議が開催され（於イギリス），欧米諸国における事例 や研究成果が報告されている ${ }^{3), 8}$ 。劣化の対象は，高速 道路橋，住宅基礎，トンネルライニング，下水管，水道 施設, 床スラブ下面, レンガ構造物の目地モルタルなど 様々である。本稿においては，国際会議での報告を中心 に，ソーマサイト生成による劣化について紹介する。

\section{3. ソーマサイトの性質と分析方法}

はじめに，ソーマサイトとは, $\mathrm{CaSiO}_{3} \cdot \mathrm{CaSO}_{4}$ ・ $\mathrm{CaCO}_{3} \cdot 15 \mathrm{H}_{2} \mathrm{O}$ の組成式で表され，低温環境下に扔いて 安定な鉱物である。天然において最初に発見されたのは 1874 年で，大抵は変成岩中に認められる。

ソーマサイトの結晶形態は写真-2 に示すとおりで, 注目すべき特徴は，硫酸塩劣化環境下における代表的な 劣化生成物であるエトリンガイト $\left(\mathrm{Ca}_{3} \mathrm{Al}_{2} \mathrm{O}_{6} \cdot 3 \mathrm{CaSO}_{4}\right.$. $\left.32 \mathrm{H}_{2} \mathrm{O}\right)$ と非常に類似した針状の結晶形態と構造をむつ ことである。

鉱物学的に，ソーマサイトはエトリンガイトのグルー プに属する。エトリンガイトの結晶は， 6 配位の $\mathrm{Al}$ 原 子を頂点とした構造が 2 単位繰り返し, その周囲に 3 個 の $\mathrm{SO}_{4}{ }_{4}^{2-}$ と 1 個の水分子が配位した構造で，三方晶系に 属し, $a=11.23 \AA ， c=21.50 \AA$ である。ソーマサイト の結晶は， $\mathrm{Al}$ 原子を 6 配位の $\mathrm{Si}$ 原子が置換して繰り返 しが 1 単位となり，その周囲に配位する陰イオンが $\mathrm{SO}_{4}{ }^{2-} 1$ 個と $\mathrm{CO}_{3}{ }^{2-} 1$ 個になったもので，六方晶系に属し， $a=11.04 \AA, c=10.39 \AA$ である10。

結晶構造がエトリンガイトと類似しているため, 分析 試験においては，エトリンガイトと䛊って判断しないよ う，両鉱物を識別することが非常に重要となる。

以下（1)〜（3）にエトリンガイトとソーマサイトを
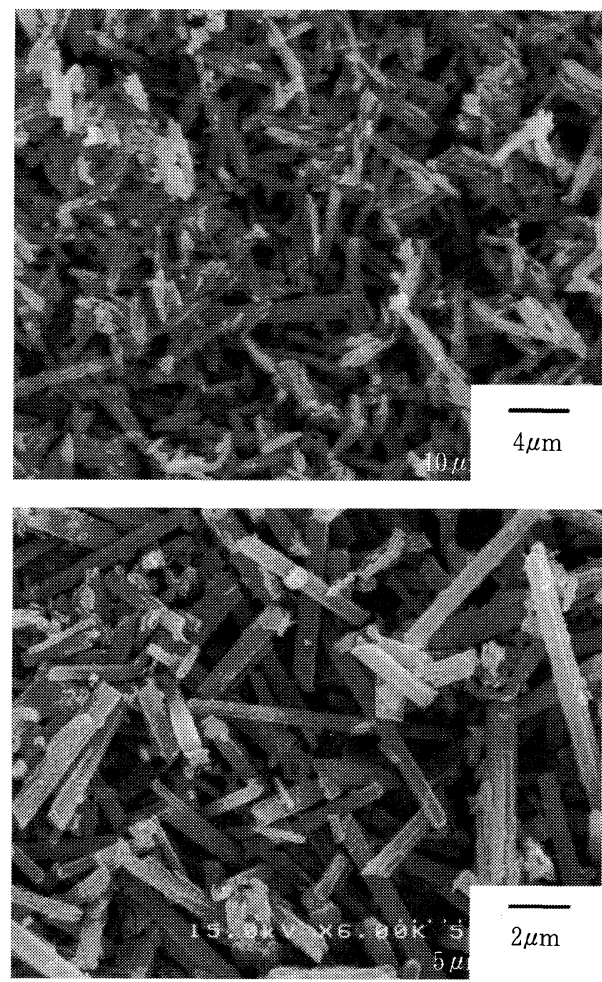

写真-2 SEM（走査型電子顕微鏡）により観察された エトリンガイト（上）およびソーマサイト (下 $)^{9)}$

識別する分析方法を紹介する。また，（4）にソーマサ イトの純物質の合成方法について付記する。

（1） SEM-EDS（エネルギー分散型 X 線分光装置 付き走查型電子顕微鏡）を用いる方法 ${ }^{11}$

SEM-EDS とは，SEM（走查型電子顕微鏡）により 電子像を観察しながら，サンプルから放出される特性 X 線を，EDS（エネルギー分散型 X 線分光装置）により 検出して，構成元素を同時に分析する装置である。

両鉱物は結晶の形態が類似しているため，SEM 像の みでは識別が困難である。しかし，EDSによる元素分 析を同時に行い, $\mathrm{Al}$ が多く検出されればエトリンガイ トであり，Si が検出されればソーマサイトであると識 別できる（図-1，図-2参照）。これは，エトリンガイト は, $\mathrm{Al}$ サイトの $1 / 2$ 程度が $\mathrm{Si}$ と置換し得るが, ソーマ

Thaumasite Form of Sulfate Attack

-A Review of the Deterioration Mechanism and the Evaluating Method of Risk-

By N. Yoshida and K. Yamada

Concrete Journal, Vol.43, No.6, pp.20 27, Jun. 2005

Synopsis In Western countries, new chemical deterioration mechanism of the concrete, "Thaumasite form of Sulfate Attack" draws attention. Thaumasite is formed when the sulfate ion mainly from the soil and carbonate ion mainly from the carbonate aggregate react with the calcium silicate hydrate under the condition of low temperature and existence of water. Thaumasite softens the cement composition and causes cracking and spalling of the concrete surface. Authors have obtained the knowledge about this deterioration from the reports by Western researchers, and would like to supply useful information in this paper.

Keywords : thaumasite, sulfate attack, sulfate ion, carbonate ion, carbonate aggregate, condition of low temperature, oxidation of pyrite 


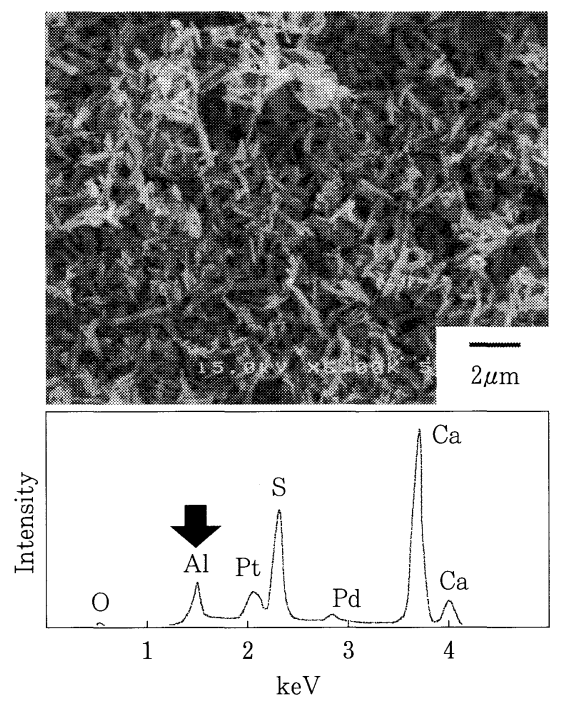

図-1ＳEM-EDS による分析結果 (エトリンガイト) $)^{9)}$

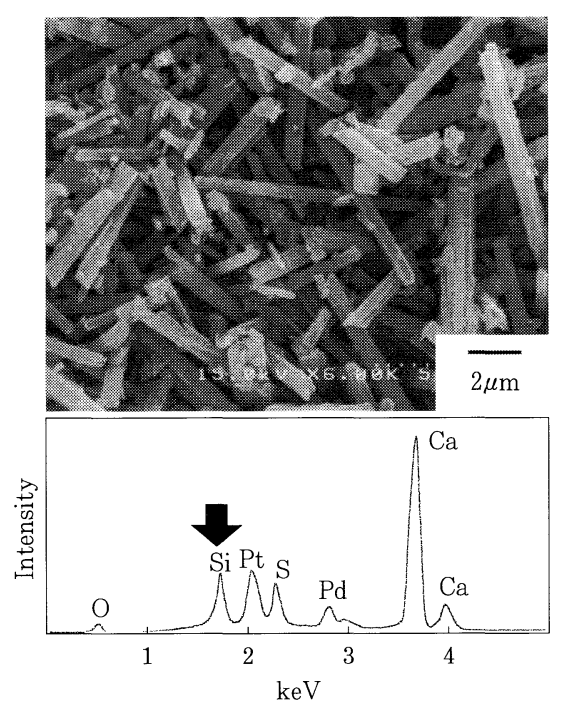

図-2 SEM-EDS による分析結果 (ソーマサイト $)^{9)}$

サイトは，Si サイトに $\mathrm{Al}$ をほとんどもしくは全く許容 しないという特徵を有することによる。

ソーマサイト中の C 原子に着目した分析は，エトリ ンガイトが炭酸化の影響を受けやすいことと, EDS の C 原子の検出感度が低いことから, SEM-EDS では難し い。 $\mathrm{C}$ 原子に対しても十分な感度を持つ EPMA（電子 プローブマイクロアナライザ）を用いると判別可能であ る $^{9)}$ 。

（2）XRD（粉末 X 線回折）を用いる方法 ${ }^{11)}$

通常の XRD パターンでは，定性分析に有用な第一ピー クが近接しているため（エトリンガイトは $2 \theta=9.08^{\circ}$, ソーマサイトは $\left.2 \theta=9.15^{\circ}\right)$ ，両鉱物を識別することは 困難である。

しかし，低 $\mathrm{pH}$ 環境において不安定なエトリンガイト は， $\mathrm{Na}_{2} \mathrm{CO}_{3}$ 溶液で処理すると溶解する性質を有する。 よって, サンプルを $\mathrm{Na}_{2} \mathrm{CO}_{3}$ 溶液で処理した後に, 残渣 をXRD 分析すると, エトリンガイトの場合, 回折ピー クが消隇する（図-3 参照, 分析条件： $5 \% \mathrm{Na}_{2} \mathrm{CO}_{3}$ 溶液

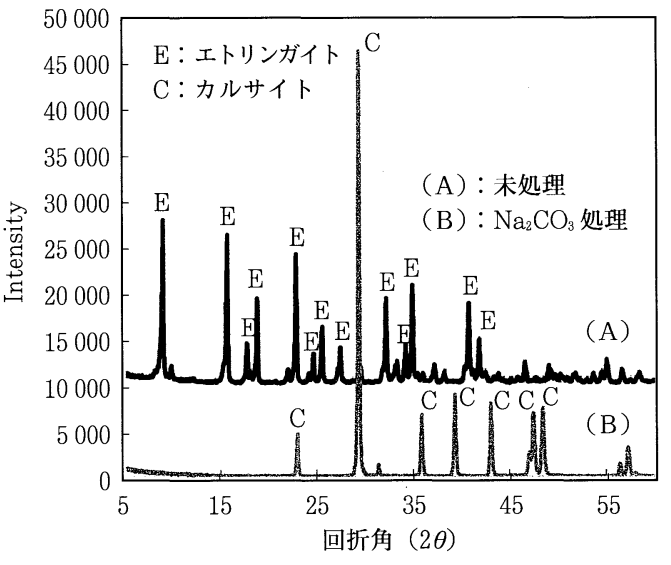

図-3 エトリンガイトの XRD パターン99

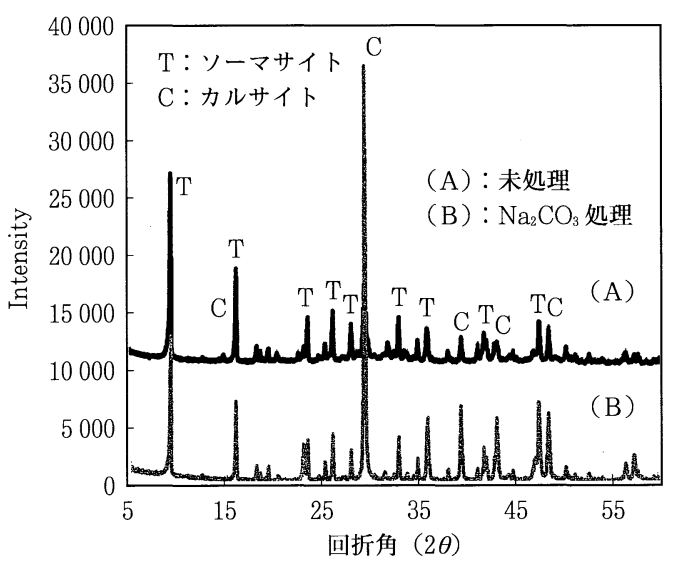

図-4 ソーマサイトの XRD パターン9)

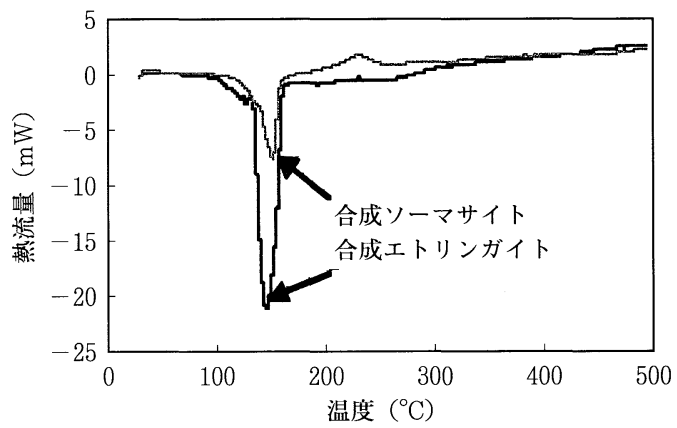

図-5 ソーマサイトおよびェトリンガイトの DSC パターン99

$100 \mathrm{ml}$ 中に試料 $5 \mathrm{~g}$ を 1 時間浸せき)。一方，ソーマサ イトは, ほとんどが溶解せずに残存するため, 処理後む ピークが現れる（図-4参照）。これにより，エトリンガ イトとソーマサイトの識別が可能である。

（3）その他の分析方法

SEM-EDS, XRDの他にも, DSC（示差走査熱量分 析装置) による方法 ${ }^{9)}$ (図-5 参照, 吸熱ピーク温度の違 いにより識別), 固体 NMR（固体核磁気共鳴装置）に より ${ }^{29} \mathrm{Si}$ (ソーマサイトの結晶に特徴的な 6 配位の $\mathrm{Si}$ ) を分析する方法 ${ }^{12)}$, IR およびラマン分光分析による方 法 ${ }^{13)}{ }^{14)}$ などの適用が報告されている。また, 偏光顕微鏡 観察による分析方法が, 劣化したコンクリートの劣化段 階を判別するために用いられているが，これについては 
後述する。

基本的に，SEM-EDS を用いた方法が広く適用され ているが，例えば，DSC は試料量が約 $10 \mathrm{mg}$ 程度で分 析が可能であることや，固体 NMR は所有している分 析機関は限定されるむのの正確な分析が行えるなどの長 所があり, 目的に応じて分析方法を選択するのが良いと 考えられる。

（4）ソーマサイトの合成方法

XRD により定量分析を行う場合や，DSCによる吸熱 ピークの温度を確認する際などには, ソーマサイトの純 物質が必要となる。

ソーマサイトの合成方法はいくつ加提案されているが, ここでは, Aguileraらの方法 ${ }^{15)}$ 紹介する。

混合手順は以下の(1)～(3)に示すとおりである。

(1) $5{ }^{\circ} \mathrm{C}$ のスクロース $10 \%$ 溶液に $0.05 \mathrm{~mol} / 1$ となるよ

うに $\mathrm{CaO}$ を溶解する(溶液 $\mathrm{A}$ )。

(2) $5^{\circ} \mathrm{C}$ のスクロース $10 \%$ 溶液に $\mathrm{Na}_{2} \mathrm{SiO}_{3}: 0.012 \mathrm{~mol}$

/1, $\mathrm{Na}_{2} \mathrm{CO}_{3}: 0.012 \mathrm{~mol} / 1, \mathrm{Na}_{2} \mathrm{SO}_{4}: 0.02 \mathrm{~mol} / 1$ と なるように各試薬を溶解する（溶液 B)。

(3)溶液 $\mathrm{A}$ および $\mathrm{B}$ を 1 対 1 で混合した溶液 $\mathrm{C}$ を $5^{\circ} \mathrm{C}$

にて所定の材齢（約 1 年）まで静置する。

この合成方法は，スクロースを使用することで $\mathrm{Ca}^{2+}$ の溶解度を増加させている点, $\mathrm{Na}$ 塩を使用することで Ca 塩よりも副次的な生成物を減少させている点などが 特徴である。

材齢数力月では，ほとんどソーマサイトは生成せず, 半年で微量, 1 年で相当量が生成する。高純度のソーマ サイトを得るには 2〜3 年以上が必要である。

\section{4. ソーマサイトの生成要因}

ソーマサイト $\left(\mathrm{CaSiO}_{3} \cdot \mathrm{CaSO}_{4} \cdot \mathrm{CaCO}_{3} \cdot 15 \mathrm{H}_{2} \mathrm{O}\right)$ が生 成するには，組成式から明らかなように，(1) $\mathrm{SO}_{4}{ }^{2-}$, (2) $\mathrm{CO}_{3}{ }^{2-}$, (3) $\mathrm{CaO}-\mathrm{SiO}_{2}$ (ケイ酸カルシウム), (4) $\mathrm{H}_{2} \mathrm{O}$ の供 給が必要である。また,ソーマサイトは低温において安定 なため, (5)低温環境下であることも必要条件であり,これ ら 5 つの条件を満足すると, ソーマサイトは生成する。

以下に，コンクリート実構造物における各物質の供給 源について，実例とともにまとめる。

(1) $\mathrm{SO}_{4}{ }^{2-}$ の供給源は，コンクリートが接する土壤およ び地下水などに含まれる硫酸塩（外来硫酸塩）である。 また，レンガ構造物においては，レンガに含まれる硫酸 塩 (内在硫酸塩) が原因となり, 目地モルタルが劣化し た被害が報告されている。問題となったレンガ構造物で

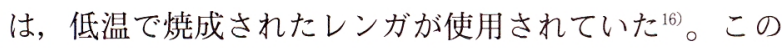
ようなレンガは，原料の粘上中に硫酸塩が含まれている 之, 焼成後も硫酸塩が残存する。なお，高温で焼成され たレンガは，問題にならないと考えられる。

(2) $\mathrm{CO}_{3}{ }^{2-}$ の供給源は, 主にコンクリート中の炭酸塩骨 材もしくは石灰石微粉末で，その他にも，コンクリート
が接する空気中の二酸化炭素や地下水㧍よび海水中の $\mathrm{CO}_{3}{ }^{2-}$ も供給源となりうる。レンガ構造物においては,

目地モルタルに用いる水硬性石灰 ${ }^{16)}$, 構造物が接する石 灰岩質地盤などが供給源として報告されている。

(3) $\mathrm{CaO}-\mathrm{SiO}_{2}$ の供給源は, セメント水和物の $\mathrm{C}-\mathrm{S}-\mathrm{H}$ や $\mathrm{Ca}(\mathrm{OH})_{2}$ である。エトリンガイト生成と大きく異な る点は, $\mathrm{C}-\mathrm{A}-\mathrm{H}$ （アルミン酸カルシウム水和物）が反 応するのではなく，硬化セメントペーストの大部分を占 める C-S-H が反応することである。したがって，劣化 が進行すると，いずれはセメントペーストの大部分がソー マサイトに変化してしまう。さらに，耐硫酸塩を目的之 したアルミン酸カルシウム $\left(\mathrm{C}_{3} \mathrm{~A}\right)$ 量の少ないセメント (耐硫酸塩セメント, 中庯熱ポルトランドセメントなど) を用いても劣化を抑止する効果はない。

(4) $\mathrm{H}_{2} \mathrm{O}$ については, 地下水位や地下水の移動性など が関連し，ソーマサイトの生成を助長する。

また，(5)低温環境について，ソーマサイトは $15^{\circ} \mathrm{C}$ 以 下で安定な鉱物であり，特に $5^{\circ} \mathrm{C}$ 付近で，生成が最も 活性となることが分かっている。この要因は, ソーマサ イトの結晶に特徴的な 6 配位の $\mathrm{Si}$ が $15^{\circ} \mathrm{C}$ 以下で安定 であること, 溶液中に存在しうる $\mathrm{CO}_{3}{ }^{2-}$ 量が増加するこ と, $\mathrm{Ca}(\mathrm{OH})_{2}$ が溶けやすくなることなどに関係するも のと考えられている(17)。

5. ソーマサイト生成によるコンクリート構造 物の劣化メカニズム

ソーマサイトが生成することにより，コンクリート構 造物が劣化するメカニズムについて，前述したイギリス の M5 motorwayに拈ける実例から紹介する。

まず，M5 motorwayに打ける，ソーマサイト生成の 要因は次のと扬りであった。

$\mathrm{SO}_{4}{ }^{2-}$ の供給源は，埋め戻しに用いた現地の土潩であ る。この地域（イギリス南西部）に広く分布するLower Lias Clay と呼ばれる石灰岩質の土䁃は, 黄鉄鉱 $\left(\mathrm{FeS}_{2}\right)$ を含有する土袞で，埋戻し土として使われる前に空気に 曝された。これにより未風化の黄鉄鉱が急激に酸化され,

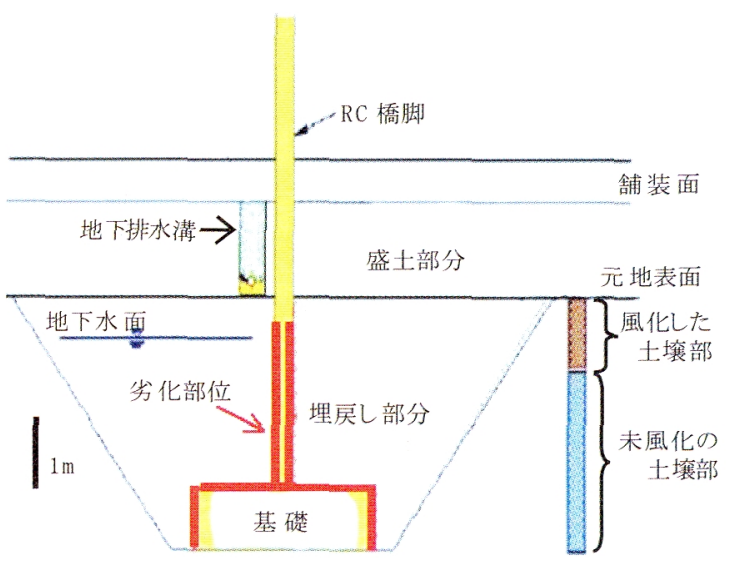

図-6 M5 motorway における劣化事例 ${ }^{5)}$ 


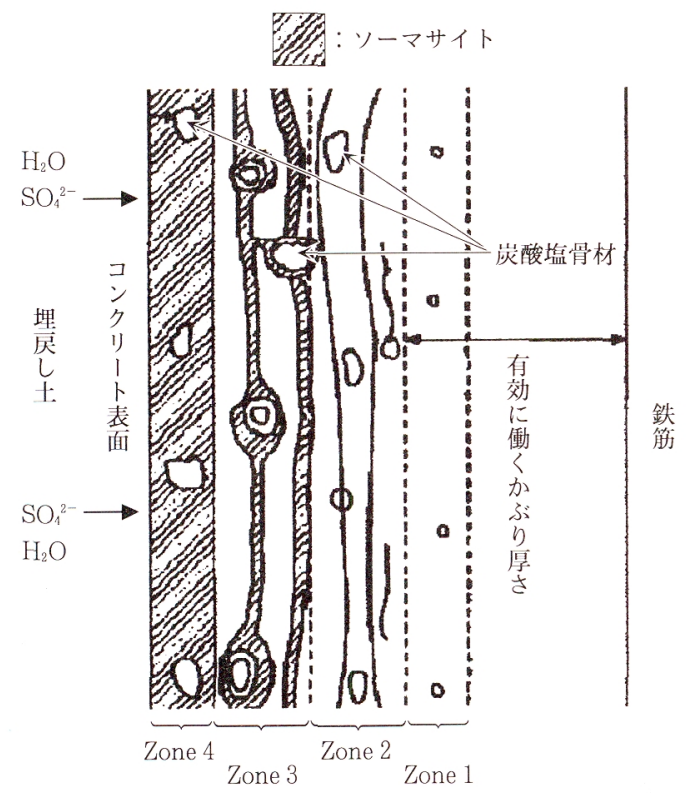

図-7 ソーマサイト生成による劣化機構模式図 ${ }^{18}$

表-1＼cjkstart各Zoneにおけるコンクリート組織の特徵18)

\begin{tabular}{|c|c|}
\hline $\begin{array}{c}\text { Zone } 1 \\
(\mathrm{TF})\end{array}$ & $\begin{array}{l}\text { 目視では劣化が明らかではない。岩石学的試験により, 空隙 } \\
\text { および龟裂に沿いソーマサイトおよびエトリンガイトが観察 } \\
\text { される。 }\end{array}$ \\
\hline Zone 2 & $\begin{array}{l}\text { ソーマサイト生成による微細煲裂が，コンクリート表面に対 } \\
\text { して平行に生じ始める。 } \mathrm{CaCO}_{3} \text { が龟裂中に観察されること } \\
\text { がある。細かな } \mathrm{Ca}(\mathrm{OH})_{2} \text { がセメントペーストマトリックス } \\
\text { に観察される。 }\end{array}$ \\
\hline Zon & $\begin{array}{l}\text { ソーマサイト生成による龟裂が大きくなり，健全なセメント } \\
\text { ペーストマトリックスが減少する。炭酸塩骨材 } \mathrm{CO}_{3}{ }^{2-} \text { の供 } \\
\text { 給源）の周囲にソーマサイトの輪が観察される。 } \mathrm{CaCO}_{3} \text { が } \\
\text { 龟裂中に観察されることがある。健全なセメントペーストマ } \\
\text { トリックスに } \mathrm{Ca}(\mathrm{OH})_{2} \text { が観察されなくなる。 }\end{array}$ \\
\hline Zone 4 & $\begin{array}{l}\text { セメントペーストマトリックスの大部分がソーマサイトとな } \\
\text { る。ソーマサイトに包まれた骨材が幾らか残存している。 }\end{array}$ \\
\hline
\end{tabular}

その過程で生じた硫酸が周网の石灰岩と反応してセッコ ウを生じ，埋め戻した後に硫酸塩環境を厳しいものにし た2) (図-6 参照)。

$\mathrm{CO}_{3}{ }^{2-}$ の供給源は，粗骨材に用いられたドロマイト $\left(\mathrm{CaMg}\left(\mathrm{CO}_{3}\right)_{2}\right)$, 細骨材に用いられた石灰石 $\left(\mathrm{CaCO}_{3}\right)$ である。

また，TSAが広く認められた箇所は，地下排水溝よ り下方の, 土壌に水分を多く含む部位で, 劣化深さは最 大約 $70 \mathrm{~mm}$ に達し（平均：約 $25 \mathrm{~mm}$ ), 錆びた鉄筋が 露出している部分む見られた。

コンクリート橋脚がソーマサイト生成により劣化に至っ たメカニズムは次のように説明されている（図-7参照）。

硫酸塩は外部加ら侵入するため，ソーマサイト生成は コンクリート表面より進行する。劣化の過程は，コンク リート組織の特徽から, Zone 1〜Zone 4 として分類さ れており，各Zoneにおけるコンクリート組織の特徵は， 表-1に示すとおりである ${ }^{19)}$

まず，ソーマサイトは，Zone 1 に示すように，コン クリートの空隙や, 他の劣化現象によって生じたひび割

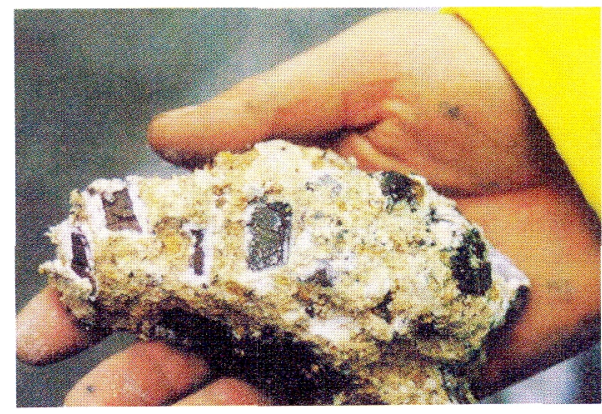

copyright BRE

写真-3 ソーマサイト生成によるコンクリートの劣化 ${ }^{6) * 1}$

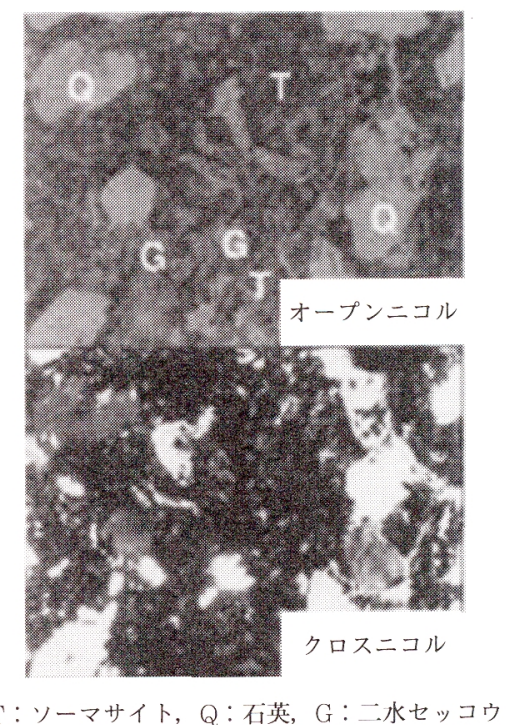

写真-4 モルタルの偏光顕微鏡写真9

れなどを埋めるように生成する。この状態は，コンクリー 卜の劣化には直接的な影響を及ぼさない潜伏期にあたり, ソーマサイト生成による劣化「TSA」とは区別して, $\lceil T F$ (Thaumasite Formation)」と呼ばれている。な お, TF は必ずしも劣化に至るものではなく, 区別して 認識する必要性がある。

さらに $\mathrm{SO}_{4}{ }^{2-}$ 抢よび $\mathrm{CO}_{3}{ }^{2-}$ が供給されると, ソーマサ イトは炭酸塩骨材の周册より C-S-H を置換するように 生成し (Zone 2 Zone 3, 写真-3 参照), 最終的には, セメントペーストマトリックスの大部分がソーマサイト となる (Zone 4, 写真-1参照)。

Zone 4 で表される大部分がソーマサイトにより構成 される組織は，「マッシュ (mash) 状」と表現されてお り，指で突くだけで簡単に崩れ落ちるような非常に脆い 組織となる。

エトリンガイト生成や二水セッコウ生成による劣化之 異なる点は, 鉱物が生成する際の結晶成長压が劣化を導 くのではなく, 組織自体をマッシュ状に変化させてしま うことで，压縮強度および接着強度が著しく低下し，コ ンクリートの崩壊を導くことである（ただし，ソーマサ イト生成に执いて屯幾分かの結晶成長圧を伴い，劣化の 進行を助長する)。 
劣化診断においては，ソーマサイト生成による劣化段 階を確認するために，モルタルおよびコンクリート試料 加ら薄片を作製し，偏光顕微鏡により組織観察を行う方 法が用いられている。

例として，ソーマサイト生成による劣化が生じている 目地モルタルについて, 偏光顕微鏡観察を行った結果を 写真-4 に示す ${ }^{13)}$ 。

骨材を除いたセメントペーストマトリックス部分は, 少量存在するセッコウを除いて，ほぼ完全にソーマサイ トの針状結晶で形成されている。これより，モルタル試 料の劣化段階は, Zone 4 に達しているものと判定され る (表-1 参照)。

なお，偏光顕微鏡観察においても，結晶構造の類似し たエトリンガイトとソーマサイトを識別することは困難 であるため，SEM-EDS やXRD などの方法により，両 鉱物の識別を行っておく必要がある。

\section{TSA の対策例}

TSAの対策としてはソーマサイトの生成要因を制限 することが重要であり, 地質調查, 環境調査, コンクリー 卜の水密性の改善（低水セメント比，混和材の使用，表 面被覆など)，炭酸塩骨材の制限などが有効であると考 えられる。M5 motorway の例では, 劣化した橋脚は補 修されず取り替えられたが，この際に，炭酸塩骨材の不 使用, 混和材の使用, 透水性の低いコンクリートの使用, 排水処理, 埋戻し材の変更, といった対策が行われ た ${ }^{19), 20)}$ 。

また，BRE (Building Research Establishment) は, M5 motorwayにおいてTSA を認識した後に，化学的 劣化環境におけるコンクリート仕様書を早急に改訂し, BRE Special Digest 1 として詳細にまとめている⿸尸

簡単に説明すると，まず，土地の調査（硫酸塩および 硫化物量測定, $\mathrm{pH}$ 测定, 地下水が動的か静的かの確認 など）を行い, 土地の化学的劣化環境の厳しさを判定す る。化学的劣化環境は, 土壌中の水溶性 $\mathrm{SO}_{4}{ }^{2-}$ 濃度また は全潜在的 $\mathrm{SO}_{4}{ }^{2-}$ 濃度, 地下水中の $\mathrm{SO}_{4}{ }^{2-}$ 濃度により, 5 段階に分類されており（表-2参照），その他の要素を 加え，さらに16クラスに分類されている。

表-2 $\mathrm{SO}_{4}{ }^{2-}$ 濃度による化学的劣化環境の分類 ${ }^{6) * 1}$

\begin{tabular}{|c|c|c|c|}
\hline 分類 & $\begin{array}{c}\text { 土壤の水溶性 } \mathrm{SO}_{4}{ }^{2-} \\
\text { 濃度 }(\mathrm{g} / \mathrm{L})^{* 1}\end{array}$ & $\begin{array}{c}\text { 地下水中の } \mathrm{SO}_{1}{ }^{2-} \\
\text { 濃度 }(\mathrm{g} / \mathrm{L})\end{array}$ & $\begin{array}{l}\text { 全潜在的 } \mathrm{SO}_{4}^{2-} \\
\text { 濃度 }(\%)^{* 2}\end{array}$ \\
\hline 1 & $<1.2$ & $<0.4$ & $<0.24$ \\
\hline 2 & $1.2 \sim 2.3$ & $0.4 \sim 1.4$ & $0.24 \sim 0.6$ \\
\hline 3 & $2.4 \sim 3.7$ & $1.5 \sim 3.0$ & $0.7 \sim 1.2$ \\
\hline 4 & $3.8 \sim 6.7$ & $3.1 \sim 6.0$ & 1. $3 \sim 2.4$ \\
\hline 5 & $>6.7$ & $>6.0$ & $>2.4$ \\
\hline $\begin{array}{l}* 1 \\
* 2 \\
\end{array}$ & $\begin{array}{l}\text { 抽出条件は，水：土境 } \\
\text { 黄鉄鉱のような硫化物 } \\
\text { する。全イオウ量を測 } \\
\text { る } \mathrm{SO}_{4} \% \text { で表す)。 }\end{array}$ & $\begin{array}{l}2: 1 \text { (啠量比) } \\
\text { 酸化が要因よなる } \\
\text { し，計算により求に }\end{array}$ & $\begin{array}{l}\text { 塩土袞にのみ適に } \\
\text { （土㙥質量に刘 }\end{array}$ \\
\hline
\end{tabular}

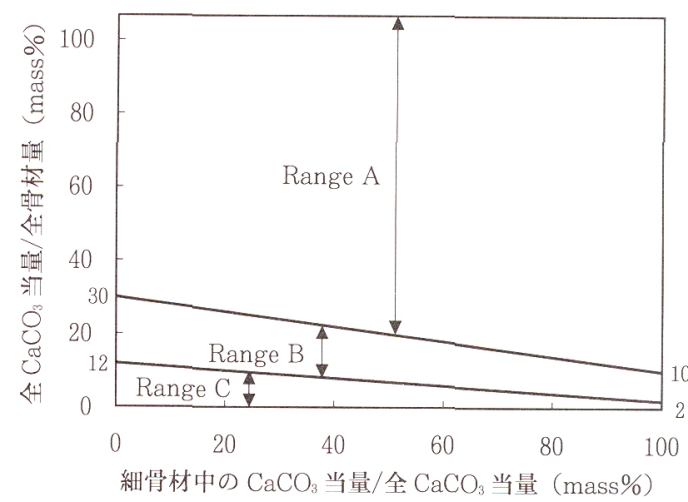

図-8＼cjkstart骨材中に含まれる炭酸塩量の分類(6)*1

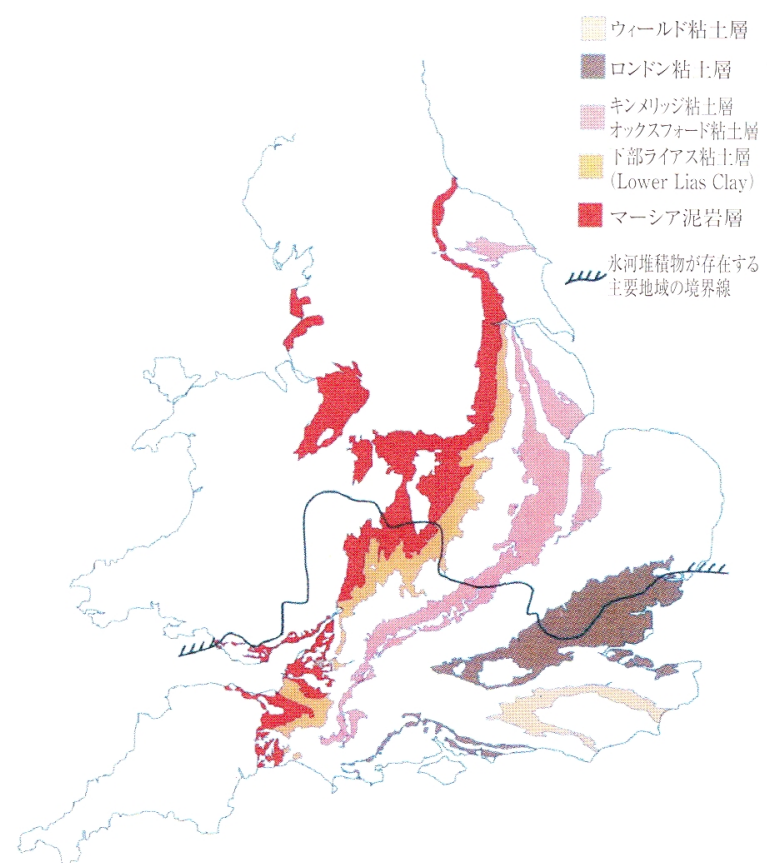

copyright BRE

図-9 イギリスにおける硫酸性地盤の分布図

次に，判定された化学的劣化環境クラスと，コンクリー 卜に要求する性能（供用期間，部材厚など）や構造物の 種類（基礎，耐力壁，床スラブ，プレキャスト製品など） とを照合させて, コンクリートの仕様（セメントの種類, 最小単位セメント量, 最大水セメント比, 骨材中の炭酸 塩量), および追加の保護策（表面被覆，土地の排水処 理など）を決定する。

コンクリートの仕様の要素には, ソーマサイト生成を 考慮して，骨材中に含まれる炭酸塩量が規定されている。

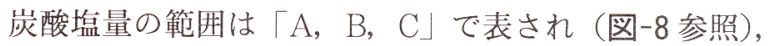
化学的劣化環境の厳しさに応じて，例えばCのような 炭酸塩量の少ない骨材を用いるように仕様が決められて いる。ここでは，炭酸塩骨材を「制限」するものであっ て，「排除」するものではない。

特に注意したい点は, 化学的劣化環境の厳しさ（劣化 外力）を的確に評価し, 劣化外力や構造物の重要性に応 じた合理的対策を講じるという方針である。種々の利点 
のある炭酸塩系骨材を一律に考えてはならない。

なお，イギリスのような，歴史的に硫酸塩劣化が多い 国では，硫酸性地盤の分布図が示されており（図-9 参 照)，技術者に対策への注意が促されている。

7. 日本における TF および TSA の可能性につ いて

前述したとおり，コンクリート構造物においてソーマ サイトが生成するには，以下の条件を同時に満足する必 要がある。

1）低温環境 $\left(15^{\circ} \mathrm{C}\right.$ 以下)

2）硫酸塩環境

3）炭酸塩骨材および石灰石微粉末の使用

4）水分の供給

日本の気温について, 平成 15 年の年間平均気温は, 全国平均で約 $15^{\circ} \mathrm{C}$ である ${ }^{21)}$ 。年間平均気温が $15^{\circ} \mathrm{C}$ を 下回る地域は, 47 都道府県のうち 21 道県で, 特に, 北 海道では例年 $10^{\circ} \mathrm{C}$ を下回る。このように，日本におい ても，一定の期間はソーマサイトの生成条件を満たす地 域が存在する。

しかし，そもそも硫酸塩環境が少ない日本においては， 硫酸塩劣化の事例も稀少である。現状において特に問題 とされているのは, 温泉地や化学工場などの特定の地域 である。このような化学的劣化環境に用いるコンクリー トとして，例えば土木学会のコンクリート標準示方書 ${ }^{22}$ では，「硫酸イオンを $0.2 \%$ 以上含む土や水に接する場 合は，水セメント比を $50 \%$ 以下とする事で照査に代え てよい」としている。欧米における事例を勘案すると, 高品質なコンクリートにおいてはTSA が生じる可能性 は低いものと思われる。また, 硫酸塩を含む海洋環境下 について, 北海道の低温海水中へのモルタル暴露実験 （浸せき 1 年）では, ソーマサイト生成は確認されてい ない昂。

ただし，日本においても，イギリスで問題となったよ うな，硫化物（特に黄鉄鉱）を含む潜在的な硫酸性地盤 が原因となり，コンクリート構造物が劣化した事例が報 告されている到えは23), 24)。施工後に $\mathrm{SO}_{4}{ }^{2-}$ が発生, 濃集し, 含水硫酸塩であるミラビライトが生成して, その結晶成 長圧で劣化が生じた。このような, 想定外の地域に突発 的に生じた硫酸塩環境下において，1），3）および4）の 条件を満たし, さらに, 水密性の低いコンクリートが用 いられた場合には，TF および TSA が生じる可能性は 否定できない。ただし，限定されるケースである。

以上のことから，日本において TF および TSA が生 じる可能性は, 否定する事はできないが，低いものと推 定される。

しかし, 硫酸塩劣化が生じたコンクリート構造物を診 断する際には, ソーマサイト生成をも想定した分析を行 うことで，可能性を見過ごさないように注意を払い，一
定環境条件については対策を行う必要性はある。特に, 潜在的な硫酸性地盤には注意を要する。これはTSAに 限らず，すべての硫酸塩劣化に関連する。現状において， このような土壌を評価する体系は整えられていないが, 試験方法については, 地盤工学会が規定する土壌中の水 溶性硫酸塩含有量試験などがある ${ }^{25)}$ 。このような試験を 用いた土壤の化学的評価体系を整備する必要性があるも のと考えられる。

\section{8. おわりに}

本稿においては，ソーマサイト生成によるコンクリー 卜構造物の劣化現象について, 現在得られている知見を 整理した。

日本における TF や TSA の可能性は低いものと思わ れるが, ソーマサイト生成の問題は, コンクリートの試 験方法や診断技術にも，新たな課題をいくつか投げかけ ている。

$\mathrm{TF}$ およびTSA は，欧米諸国においても長い間発見 されなかったが，この一因は，以下のように考えられて いる ${ }^{17)}$ 。

1）従来の耐硫酸塩試験では $\mathrm{TF}$ および $\mathrm{TSA}$ は検出 されない。

2）分析上エトリンガイトとの区別が難しかった。

3）地中構造物の調査は一般にされない。

4）硫化物の酸化により, 施工後に $\mathrm{SO}_{4}{ }^{2-}$ 濃度が増加 した。

これらより，実環境に応じた試験技術の開発，適切な 試験方法・試験手順の整備, 簡易な地中構造物の調査手 法や，土壌の化学的評価体系などへの更なる検討が望ま れる。

TSA は，コンクリートに起こりうる化学的侵食を正 しく理解するためにも重要な現象であり, 今後む新たな 情報を発信していきたいと考えている。

\section{参 考 文 献}

1）土木学会：コンクリートの化学的侵食・溶脱に関する研究の現状, コンクリート技術シリーズ 53, 2003

2) N.J. Crammond : Under attack, Bridge Design \& Engineering, Second quarter, pp. 51-53, 2001

3) Building Research Establishment : Proceedings of the First International Conference on Thaumasite in Cementitious Materials, 2002

4）吉田夏樹：コンクリート構造物における硫酸塩劣化の現状一ソー マサイト生成による新たな劣化問題一, GBRC, Vol.28, No.4, pp. 32 38, 2003

5) T.I. Longworth : Contribution of construction activity to aggressive ground conditions causing the thaumasite form of sulfate attack to concrete in pyritic ground, Proceedings of the First International Conference on Thaumasite in Cementitious Materials, Paper No. 14, 2002

6) Building Research Establishment Limited, UK : Concrete in aggressive ground. BRE Special Digest 1. BRE Bookshop, Bucknalls Lane. Watford. WD25 9XX. UK, 2001 edition

7) B. Erlin and D.C. Stark : Identification and occurrence of thaumasite in concrete, Highway Research Records, No.113, pp. 108-113, 1965 
8）氏家 勲: 第 1 回タマサイト国際会議, コンクリート工学, Vol. 40, No. 12, pp. 45 48, 2002. 12

9）平尾 宙・山田一夫・広野真一・森 大介：モルタル中に生成し たソーマサイトの分析方法とコンクリートへの適用, セメント・ コンクリート論文集, No.58,pp. 225〜232，2004

10) H. Taylor : Cement Chemistry Second Edition, Thomas Telford publication, pp.166-169, 1997

11) J.H.P. van Adardt and S. Visser : Thaumasite formation : a case of deterioration of Portland cement and related substances in the presence of sulphates, Cem. Conc. Res., pp. 225-232, 1975

12) J. Skibsted, S. Rasmussen, D. Herfort and H.J. Jakobsen : ${ }^{29} \mathrm{Si}$ cross-polarization magic-angle spinning NMR spectroscopyan efficient tool for quantification of thaumasite in cementbased materials, Proceedings of the First International Conference on Thaumasite in Cementitious Materials, Paper No. 9, 2002

13) S. Prakash Varma and J. Bensted : Studies of thaumasite, Silicates Industriels, Vol.38, pp. 29-32, 1973

14) J. Bensted and S. Prakash Varma : Studies of thaumasitePart II , Silicates Industriels, Vol.38, pp.11-19, 1974

15) J. Aguilera, M. T. Blanco Varela and T. Vazquez : Procecure of synthesis of thaumasite, Cem. Conc. Res., Vol.31, pp.11631168,2001

16) R.P.J. van Hees, T.J. Wijffels and L.J.A.R. van der Klugt : Thaumasite swelling in historic mortars : field observations and laboratory research, Proceedings of the First International
Conference on Thaumasite in Cementitious Materials, Paper No. 71, 2002

17) N.J. Crammond: The thaumasite form of sulfate attack in the UK, Proceedings of the First International Conference on Thaumasite in Cementitious Materials, Paper No.17, 2002

18) R. G. Sibbick, N. J. Crammond and D. Metcalf : The microscopical characterization of thaumasite, Proceedings of the First International Conference on Thaumasite in Cementitious Materials, Paper No. 14, 2002

19) J. Wallace : Finding thaumasite sulfate attack-consequences for works in progress, Proceedings of the First International Conference on Thaumasite in Cementitious Materials, Paper No. 22, 2002

20) N. Loudon: A review of the experience of thaumasite sulfate attack by the UK Highways Agency, Proceedings of the First International Conference on Thaumasite in Cementitious Materials, Paper No.47, 2002

21）気象業務支援センター：気象庁年報 2003 年

22）土木学会：コンクリート標準示方書[施工編], 2002

23）高谷精二：束石崩壊の発生した地域にみられる塩類集積現象につ いて, 土と基礎, Vol.31, No.1, pp.101〜104, 1983

24）陽田秀道：新第三紀層泥岩の生化学的風化現象と被害, 土木学会 論文集, No.617/无 -46, pp. 213〜224，1999.3

25）地盤工学会：土の水溶性成分試験方法（JGS0241-2000），2000

※1 reproduced from BRE Special Digest 1, with permission

\section{コンクリート構造物のポストピーク挙動評価と設計への応用}

重要な構造物の設計においては, ポストピーク挙動に関する情報は必須と言っても良い。本書は,「コンクリート構造物のポ ストピーク挙動解析に関する研究委員会」(委員長：田辺忠顕 名古屋大学大学院教授）4年間の活動において, コンクリート 構造物のポストピーク挙動に関して活発に議論した内容, 特に, 各種コンクリート構造物のポストピーク挙動, 耐荷力とポスト ピーク挙動を予測するための最新の非線形解析手法, ポストピーク領域の設計への応用などについて, 有用な成果をとりまとめ たものである。

1. ポストピーク挙動評価の工学的意義 2. $\mathrm{RC}$ 構造物のポストピーク挙動に関する実験的検討

3. 材料レベルのポストピーク挙動とそのモデル化 4. ポストピーク領域の数值解析法

5. $\mathrm{RC}$ 構造物のポストピーク挙動の解析 6. 衝撃の問題に対するポストピーク解析の応用

7. ポストピーク挙動評価と設計への応用

参考文献

索引

B 5 判・277 ページ（2003 年刊行）／定価 10500 円（税込), 会員特価 9450 円（税込）／送料 390 円

・申込先：(社) 日本コンクリート工学協会「書籍販売」係

厂102-0083 東京都千代田区趜町 1-7 相互半蔵門ビル 12 階／電話（03）3263-1573

〈申込方法〉 郵便振替（振替口座：00120-5-99133・加入者名：社団法人日本コンクリート工学協会）にて払い込み・ お申込み下さい。代金（書籍代・送料合計）受領次第お送りします（振替手数料は申込者にてご負担願います）。

通信欄に書籍名・冊数・当協会会員の場合は会員番号を明記して下さい。

ご依頼人欄（お届け先）に郵便番号・住所・名称・担当者名・電話番号を必ず明記して下さい。 送料は 1 冊分の金額ですので，2冊以上お申込みの場合は，お問合せ下さい。 